\title{
GLOMALES I: A MONOGRAPH OF Glomus spp. (Glomaceae) IN THE SUNFLOWERRHIZOSPHERE OF HARYANA, INDIA
}

\author{
Sharma, S., Parkash, V. and Aggarwal, A. ${ }^{*}$
}

Botany Department, Kurukshetra University,

Kurukshetra-136119, Haryana, India

Received: June 24, 2007

Accepted: September 10, 2008

SUMMARY

Seven species of Glomus (Glomus mosseae, G. fasciculatum, G. scintillans, G. versiforme, G. geosporum, G. macrocarpum and G. diaphanum) from sunflower rhizosphere are described and illustrated. A key to species of the genus Glomus is also prepared based on morphological characters. Spores of these species were identified on the basis of their morphological characters such as hyphal attachment, spore ornamentation, wall layers and spore color and size.

Key words: sunflower rhyzosphere, Glomus species, Vesicular Arbuscular Mycorrhizal fungi (VAM)

\section{INTRODUCTION}

Members of Endogonaceae are widely distributed in agricultural and forest soils throughout the world. Among arbuscular endomycorrhizal fungi in the order Glomales, 56\% of the described species are in the genus Glomus (Morton and Benny, 1990), including species formerly in the genus Sclerocystis (Almeida and Schenck, 1990). Species of Glomales are separated by morphological characters residing mostly in a variety of subcellular structures in spores that have been defined as "layers" (Berch, 1987), walls (Walker, 1983) or zones (Maia et al., 1993). However, no effort seems to have been directed to isolate and describe VAM fungi associated with the sunflower. With this objective, surveys were conducted to isolate and identify species of Glomus on sunflowers in Haryana, India.

* Corresponding author: e-mail: aggarwal_vibha@rediffmail.com 


\section{MATERIALS AND METHODS}

An extensive investigation of Glomales in the sunflower rhizosphere in Haryana, India, had been conducted to collect various species from various areas using wet sieving and decanting technique (Gerdemann and Nicolson, 1963). Spores were multiplied in the greenhouse with maize as host plant. For taxonomic purpose, spores were mounted in PVLG medium.

\section{RESULTS AND DISCUSSION}

All seven species of the genus Glomus were isolated and identified by using manuals of Trappe (1982), Morton and Benny (1990), Schenck and Perez (1990) and Mukerji (1996).

\section{Glomus}

The genus includes both sporocarpic and non-sporocarpic species. Those with chlamydospores develop the spores terminally, on a single undifferentiated hypha. The spores are formed at the end of a hypha which may be constricted at the point of attachment to the spore, have parallel side walls, or become markedly occluded at the point of attachment to the spores. The spore wall can have one to many layers, without ornamentation. Germination is either into old subtending hypha or more rarely through the spore wall. Vesicles and arbuscules have been found in Glomus.

\section{Glomus mosseae (Nicol. and Gerd.) Gerd. and Trappe}

Spores rarely filled with hyphae, sporocarp containing 1-10 spores (sometimes), diameter of subtending hypha at widest part $18-50 \mu \mathrm{m}$, outer surface of inner wall is not ornamented; thin, hyaline outer wall may not be obvious. Spores are more than $100 \mu \mathrm{m}$ in size, subtending hypha is generally funnel-shaped with cup-shaped septum (Figure $1 \mathrm{~A}$ and B).

\section{Glomus fasciculatum (Thaxter sensu Gerd.) Gerd. and Trappe}

Chlamydospores formed in loose aggregation in sporocarp; chlamydospores are $80-120 \mu \mathrm{m}$ when globose, smooth or seemingly rough from adherent debris. Spore wall is $4.2 \mu \mathrm{m}$ thick, hyaline to yellow, the thicker walls often minutely perforated with thick inward projections, hyphal walls occluded at maturity (Figure $1 \mathrm{E}$ and $\mathrm{F}$ ).

\section{Glomus geosporum (Nicol. and Gerd.) Walker}

Chlamydospores formed singly, globose to sub-globose or broadly ellipsoid, 100-250 $\mu \mathrm{m}$ in width, smooth, dark yellow-brown at maturity. Spore wall 5-20 $\mu \mathrm{m}$ thick, 2-3 layered, spore with loosely sleeve-like hyphal attachment at right angle to spore wall, at least $180 \mu \mathrm{m}$ long, $10-20 \mu \mathrm{m}$ diameter in young spores, oil droplets present in young spores (Figure $1 \mathrm{~K}$ ). 

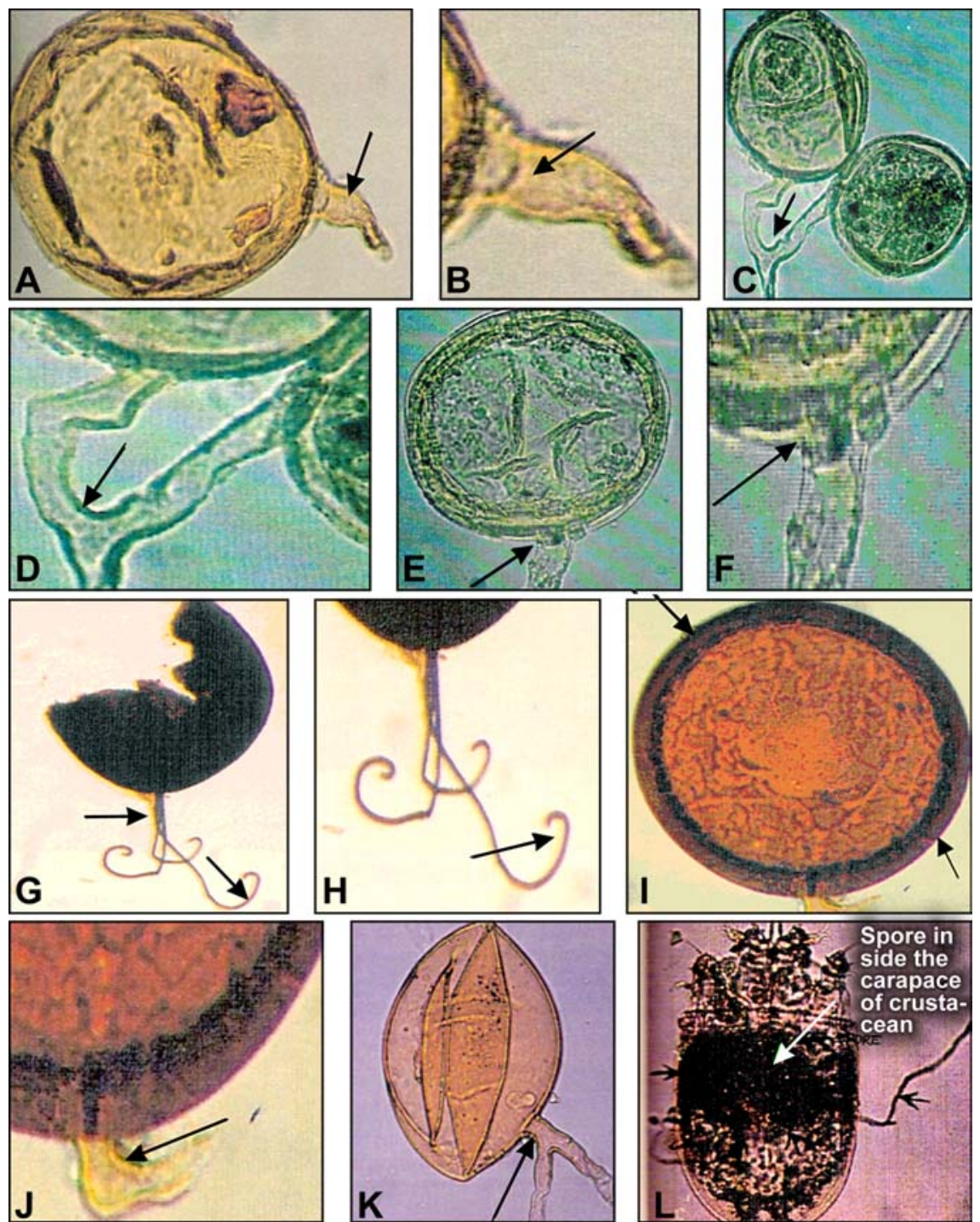

Figure 1 (A and B): Spores of Glomus mosseae $(10 \times 40 X)$, arrow shows funnel-shaped attachment (1A), cup shaped septum (1B);

Figure 1 (C and D): -spores of Glomus diaphanum $(10 \times 40 X)$, arrow shows common hyphal attachment;

Figure $1(E$ and F): -spores of Glomus fasciculatum $(10 \times 40 X)$, arrows show hyphal attachment $(E$ and $F)$;

Figure $1(G$ and $H)$ :-spores of Glomus scintillans $(10 \times 40 X)$, arrow shows hooked ends $(H)$;

Figure 1 (I and J): -spores of Glomus macrocarpum $(10 \times 40 \mathrm{X})$, arrows show much occluded hyphal attachment $(J)$ and cross channels in wall layers $(I)$;

Figure 1 (K): -spore of Glomus geosporum $(10 \times 40 \mathrm{X})$, arrow shows hyphal attachment at right angle to the spore;

Figure 1 (L): -spore of Glomus versiforme $(10 \times 40 X)$, arrow shows spore in crustacean carapace. 


\section{Glomus macrocarpum Tul. and Tul.}

Resting spores red brown to dark brown (honey colored), 120-400 $\mu \mathrm{m}$ in width, subtending hypha not inserted, spore without a plug but may be much occluded by lateral walls, spores borne singly, multilayered with cross channels in walls with lignified ingrowth from outer side of the wall (Figure $1 \mathrm{I}$ and $\mathrm{J}$ ).

\section{Glomus scintillans Rose and Trappe}

Chlamydospores formed singly, globose to sub-globose, dark brown to black in color, with long subtending hypha (1-3 rarely) with hooked ends, size of spores $>150 \mu \mathrm{m}$, spore wall not distinct, with outer rough surface (Figure $1 \mathrm{G}$ and $\mathrm{H}$ ).

\section{Glomus diaphanum Mor. and Walk.}

Azygospores borne in soil, spores mostly two in number, joined through a common hyphal attachment with mother hyphae, spores in variable shapes, yellow to yellowish brown, 100-250 $\mu \mathrm{m}$ in diameter, wall layers 2-3, irregular, subtending hyphae hyaline and convoluted (Figure $1 \mathrm{C}$ and D).

\section{Glomus versiforme Berch}

Chlamydospores borne in soil, single, germinate inside the carapace of crustaceans, brown to black in color, elliptical in shape, with long hyphal attachment, hypha not hyaline, spore size 100-200 $\mu \mathrm{m}$, wall layers inseparable, outer wall spiny (Figure $1 \mathrm{~L}$ ).

Table 1: Key to the species Glomus

\begin{tabular}{|c|c|c|}
\hline 1.1. & $\begin{array}{l}\text { Spores }>100 \mu \mathrm{m} \text { in diameter, subtending hypha generally } \\
\text { funnel-shaped with cup-shaped septum }\end{array}$ & Glomus mosseae \\
\hline 1.2 . & $\begin{array}{l}\text { Spores in loose aggregation, } 80-120 \mu \mathrm{m} \text { in diameter, globose, } \\
\text { outer wall minutely perforated with thick inward projections }\end{array}$ & Glomus fasciculatum \\
\hline 1.3 . & $\begin{array}{l}\text { Spores globose to sub-globose or ellipsoid, } 100-250 \mu \mathrm{m} \text { with } \\
\text { loosely sleeve-like hyphal attachment at right angle to spore wall }\end{array}$ & Glomus geosporum \\
\hline 1.4. & $\begin{array}{l}\text { Spores dark red-brown or honey colored, round or globose, } 120-400 \\
\mu \mathrm{m} \text { in diameter, subtending hypha not inserted, hyphal attachment } \\
\text { much occluded, spore wall multilayered with cross channels }\end{array}$ & Glomus macrocarpum \\
\hline 1.5. & $\begin{array}{l}\text { Spores globose to sub-globose, }>150 \mu \mathrm{m} \text { in size, black in color, } \\
\text { long subtending hyphae with hooked ends }\end{array}$ & Glomus scintillans \\
\hline 1.6. & $\begin{array}{l}\text { Spores mostly in group of two, joined with a common hyphal } \\
\text { attachment, size } 100-250 \mu \mathrm{m}\end{array}$ & Glomus diaphanum \\
\hline 1.7. & $\begin{array}{l}\text { Spores jet black in color, elliptical shape, } 100-200 \mu \mathrm{m} \text { in size, } \\
\text { outer wall spiny }\end{array}$ & Glomus versiforme \\
\hline
\end{tabular}

\section{ACKNOWLEDGEMENTS}

The authors Sapana Sharma and Vipin Parkash are grateful for financial assistance from Kurukshetra University, Kurukshetra, and CSIR, New Delhi, India, respectively. 


\section{REFERENCES}

Almeida, R.T. and Schenck, N.C., 1990. A revision of genus Sclerocystis (Glomaceae, Glomales). Mycologia 82: 703-714.

Berch, S.M., 1987. Endogonaceae: Taxonomy, specificity, fossil records, phylogeny. Front. Appl. Microbiol. 2: 161-188.

Gerdemann, J.W. and Nicolson, Y.H., 1963. Spores of mycorrhizae Endogone species extracted from soil by wet sieving and decanting. Trans. Br. Mycol. Soc. 46: 235-244.

Maia, L.C., Kimbrough, J.W. and Benny, G.L., 1993. Ultrastructural studies of the spore wall of Gigaspora albida (Glomales). Mycologia 85: 883-889.

Morton, J.B. and Benny, G.L., 1990. Revised classification of arbuscular mycorrhizal fungi (Zygomycetes): New order, Glomales, two new sub-orders, Glomineae and Gigasporine$a e$, and two new families, Acaulosporaceae and Gigasporaceae, with emendation of Glomoceae. Mycotaxon, 37: 471-491.

Mukerji, K.G., 1996. Taxonomy of endomycorrhizal fungi. In: Mukerji, K.G., Mathur, B., Chamola, B.P. and Chitralekha, P. (Eds. ), Advances in Botany. APH Pub. Corp. New Delhi, pp. 211-221.

Schenck, N.C. and Perez, Y., 1990. Manual for the identification of VA mycorrhizal (VAM) fungi. Univ. of Florida Press, Florida, USA, pp. 241.

Walker, C., 1983. Taxonomic concepts in the Endogonaceae spore wall characteristics in species description. Mycotaxon 18: 443-445.

\section{GLOMALES I: UNA MONOGRAFÍA DE Glomus spp. (Glomaceae) EN LA RIZÓSFERA DEL GIRASOL DE HARYANA, INDIA}

\section{RESUMEN}

Se describieron e ilustraron siete especies de Glomus (Glomus mosseae, G. fasciculatum, G. scintillans, G. versiforme, G. geosporum, G. macrocarpum y G. diaphanum) de la rizósfera del girasol. Además se preparó una clave de las especies del género Glomus sobre la base de caracteres morfológicos. Se identificaron esporas de esas especies de acuerdo con características morfológicas como adherencia hifal, ornamentación de las esporas, capas de las paredes y color y tamaño de las esporas.

\section{GLOMALES I: MONOGRAPHIE SUR LA SORTE Glomus spp. (Glomaceae) DANS LA RHIZOSPHÈRE DU TOURNESOL A HARYANA, INDE}

\section{RÉSUMÉ}

Sept espèces du genre Glomus (Glomus mosseae, G. fasciculatum, G. scintillans, G. versiforme, G. geosporum, G. macrocarpum et G. diaphanum) de la rhizosphère du tournesol sont décrites et illustrées. Une clef de détermination de l'espèce au sein du genre Glomus est préparée sur la base des caractères morphologiques. Les spores de ces espèces ont été identifiées sur des caractères morphologiques tels que l'attachement des hyphes, l'ornementation des spores, la paroi, la couleur et la taille des spores. 
